\title{
EFEKTIVITAS PENGGUNAAN E-LEARNING BERBASIS EDMODO TERHADAP HASIL BELAJAR FISIKA SISWA SMA NEGERI 2 TONDANO KELAS XI PADA MATERI SUHU DAN KALOR
}

\author{
Feyka Sinta Sigar, Ferdy Dungus, Alfrits Komansilan \\ Fakultas Matematika dan Ilmu Pengetahuan Alam, Universitas Negeri Manado \\ email: sigarfeyka@gmail.com
}

\begin{abstract}
ABSTRAK
Penelitian ini bertujuan untuk mengetahui efektivitas media pembelajaran Edmodo terhadap hasil belajar fisika siswa SMA N 2 Tondano kelas XI pada materi suhu dan kalor. Penelitian ini menggunakan metode eksperimen dan desain yang digunakan adalah dengan Posttest Only Control Group Design. Kelas eksperimen menerapkan media pembelajaran Edmodo dan kelas kontrol tanpa menggunakan media pembelajaran Edmodo. Setelah dilakukan proses pembelajaran, selanjutnya data penelitian diambil berdasarkan posttest dan menyatakan bahwa nilai rata-rata posttest kelas eksperimen yaitu 80,5 sedangkan nilai rata-rata posttest kelas kontrol yaitu 67,5. Maka hasil belajar siswa atau posttest siswa kelas eksperimen lebih tinggi dibandingkan hasil posttest siswa kelas kontrol. Dari data tersebut dilakukan uji normalitas serta uji homogenitas data dan hasil uji normalitas menunjukkan data berdistribusi normal, demikian halnya uji homogenitas menyatakan bahwa kedua kelas homogen, selanjutnya dilakukan uji-t dan diperoleh hasil yaitu $t_{\text {hitung }}$ sebesar 3,87828 dan $t_{\text {tabel }}$ sebesar 1.68595 dengan demikian $H_{0}$ ditolak dan $H_{A}$ diterima. Sehingga dapat disimpulkan bahwa penerapan media pembelajaran Edmodo lebih efektif karena rata-rata hasil belajar siswa kelas eksperimen yang menggunakan media Edmodo lebih tinggi dari rata-rata hasil belajar siswa kelas kontrol tanpa menggunakan media Edmodo.
\end{abstract}

Kata kunci : Media Pembelajaran Edmodo, Proses Pembelajaran, Hasil Belajar

\begin{abstract}
This study aims to determine the effectiveness of the Edmodo learning media on the physics learning outcomes of SMA N 2 Tondano class XI students on the material of temperature and heat. This study uses experimental methods and the design used is the Posttest Only Control Group Design. The experimental class applies Edmodo learning media and the control class without using Edmodo learning media. After the learning process was carried out, the research data was then taken based on the posttest and stated that the average posttest score for the experimental class was 80.5, while the posttest average for the control class was 67.5. So the student learning outcomes or posttest experimental class students are higher than the posttest results of control class students. From these data, normality test and data homogeneity test were carried out and the results of the normality test showed that the data was normally distributed, as well as the homogeneity test stated that the two classes were homogeneous, then t-test was carried out and the results obtained were tcount of 3.87828 and ttable of 1.68595 thus $\mathrm{HO}$ rejected and HA accepted. So it can be concluded that the application of Edmodo learning media is more effective because the average learning outcomes of experimental class students who use Edmodo media are higher than the average control class students' learning outcomes without using Edmodo media.
\end{abstract}

Keywords : : Edmodo learning media, learning process, learning outcomes. 


\section{PENDAHULUAN}

Pendidikan adalah suatu proses perjalanan individu ke arah yang lebih baik dengan berbagai potensi-potensi yang dimiliki. Perkembangan teknologi informasi dan komunikasi di era industri 4.0 telah memiliki pengaruh yang besar terhadap proses pengajaran dan pembelajaran. Teknologi saat ini sudah menjadi kebutuhan sekaligus tuntutan dalam pengaplikasian alat-alat penunjang di sekolah dan berbagai lembaga pendidikan. Kehidupan pada zaman ini memaksakan berbagai keterampilan yang perlu dikuasai seseorang, maka diharapkan pendidikan bisa mempersiapkan peserta didik sehingga mampu menguasai beragam keterampilan melalui pembelajaran dengan memanfaatkan perkembangan teknologi.

Keadaan pandemi COVID-19 memaksa kegiatan pembelajaran dilaksanakan di rumah. Hal ini berdasarkan surat edaran dari Kementrian Pendidikan dan Kebudayaan Republik Indonesia nomor 4 tahun 2020 yang dilakukan secara daring atau jarak jauh. Adapun menurut observasi awal, guru yang bersangkutan dengan pembelajaran Fisika menyampaikan bahwa siswa masih kurang aktif dalam pembelajaran daring atau jarak jauh sehingga menyebabkan rata-rata hasil belajar siswa yang rendah.

E-learning merupakan pendekatan dengan cara yang lebih inovatif sehingga dapat dijadikan sebagai satu metode dalam media penyampaian yang baik. Penggunaan $e$ learning pada kegiatan pembelajaran dapat melalui suatu sistem yaitu LMS (Learning Management System) salah satunya Edmodo. Edmodo adalah sebuah media e-learning yang dapat digambarkan secara kasaran seperti Facebook. Edmodo sendiri didirikan oleh Nicolas Borg dan Jeff O'Hara pada tahun 2008 yang didalamnya menerapkan sistem pembelajaran yang sangat sederhana, efektif, efisien, dan juga menyenangkan. Edmodo menyediakan cara yang aman dan mudah untuk berkomunikasi dan berkolaborasi antara guru dan siswa, berbagi konten berupa teks, gambar, links, video, maupun audio.

Setelah diterapkannya penggunaan $e$ learning berbasis edmodo ini yang memiliki fitur-fitur dengan manfaatnya masing-masing, diharapkan bisa menciptakan suasana pembelajaran jarak jauh yang menarik, mudah dan menyenangkan serta dapat membantu meningkatkan hasil belajar siswa khususnya pada pembelajaran Fisika materi Suhu dan Kalor.

Berdasarkan uraian diatas, maka peneliti tertarik untuk melakukan penelitian dengan judul: "Efektivitas Penggunaan E-Learning Berbasis Edmodo Terhadap Hasil Belajar Fisika Siswa SMA Negeri 2 Tondano Kelas XI Pada Materi Suhu Dan Kalor". Adapun tujuan yang ingin dicapai untuk mengetahui keefektifan penggunaan e-learning berbasis edmodo terhadap hasil belajar Fisika siswa SMA Negeri 2 Tondano kelas XI pada materi suhu dan kalor.

\section{METODE PENELITIAN}

\section{Tempat Dan Waktu Penelitian}

Penelitian ini dilaksanakan di SMA N 2

Tondano pada semester genap tahun ajaran 2020/2021.

\section{Populasi dan Sampel}

1. Populasi

Populasi dalam penelitian ini adalah siswa kelas XI IPA 1 dan XI IPA 2 SMA N 2 Tondano tahun ajaran 2021/2022

2. Sampel

Yang menjadi sampel dalam penelitian ini adalah siswa kelas XI IPA 1 yang berjumlah 20 orang siswa dan kelas XI IPA 2 berjumlah 20 orang siswa di SMA N 2 Tondano.

\section{Jenis Dan Desain Penelitian}

Berdasarkan judul dan permasalahan di atas maka jenis penelitain ini adalah eksperimen. Dalam penelitian ini, siswa dibedakan atas dua kelas yaitu kelas eksperimen dan kelas kontrol. Kedua kelas ini diberi perlakuan yang berbeda. Pada kelas eksperimen digunakan e-learning berbasis edmodo, sedangkan kelas kontrol diberi perlakuan tanpa menggunakan e-learning berbasis edmodo.

Desain eksperimen yang digunakan dalam penelitian ini berbentuk Posstest-Only Control Group Design. Responden dipilih secara purposive sampling dan diberi perlakuan untuk lebih jelasnya dapat dilihat pada tabel 1 .

Tabel 1. Desain penelitian

\begin{tabular}{lcc}
\hline Kelas/Kelompok & Perlakuan & Posttest \\
\hline Eksperimen & $X_{1}$ & $O_{1}$ \\
\hline Kontrol & $X_{2}$ & $O_{2}$ \\
\hline
\end{tabular}

Keterangan :

$X_{1}$ : Perlakuan penelitian, pembelajaran menggnunakan e-learning berbasis edmodo 
$X_{2}$ : Perlakuan penelitian, pembelajaran tanpa menggunakan e-learning berbasis edmodo

$O_{1}$ : Posttest kelas eksperimen setelah perlakuan $\mathrm{O}_{2}$ : Posttest kelas kontrol setelah perlakuan

\section{Variabel penelitian}

Terdapat dua variable dalam penelitian ini, yaitu :

1. Variable Bebas

Variabel bebas pada peneitian ini yaitu penggunaan e-learning berbasis edmodo pada materi suhu dan kalor.

2. Variable Terikat

Variabel terikat pada penelitian ini yaitu hasil belajar siswa (niklai posttest setelah diberi perlakuan).

\section{Instrumen Penelitian}

Instrumen yang digunakan dalam penelitian ini berbentuk tes yang terdiri dari soal posttest berupa soal objektif atau pilihan ganda.

\section{Teknik Pengumpulan Data}

Data yang dikumpulkan diperoleh dengan memberikan posttest setelah diterapkannya perlakuan menggunakan $e$-learning berbasis edmodo pada kelas eksperimen dan perlakuan tanpa menggunakan e-learning berbasis edmodo pada kelas kontrol.

\section{Teknik Analisis Data}

Analisis data dengan uji-t digunakan untuk menguji hipotesis. Sebelum menguji hipotesis penelitian, dilakukan uji normalitas dan uji homogenitas sebagai uji prasyarat.

Uji normalitas digunakan untuk mengetahui apakah sampel berdasarkan dari populasi berdistribusi normal atau tidak. Dengan hipotesis:

Terima $H_{0}$ : Sampel berasal dari populasi berdistribusi normal

Tolak $H_{A}$ : Sampel berasal dari populasi yang tidak berdistribusi normal

Kriteria kenormalan, jika $\mathrm{L}_{\text {hitung }}<\mathrm{L}_{\text {tabel }}$ maka data tersebut berdistribusi normal. Nilai n untuk taraf nyata $a=5 \%=0.05$.

Uji homogenitas bertujuan untuk mengetahui apakah kedua varians data homogen atau tidak homogen. Uji yang digunakan adalah uji $\mathrm{F}$, dengan rumus:

$$
F=\frac{\text { varians terbesar }}{\text { varians terkecil }}=\frac{S_{1}^{2}}{S_{2}^{2}}
$$

Hipotesis statistik sebagai berikut:

$\mathrm{H}_{\mathrm{o}}: F_{0}<F_{\text {tabel }}$ (kedua varians/ragam sama)

$\mathrm{H}_{\mathrm{o}}: F_{0}>F_{\text {tabel }}$ (kedua varians/ragam tidak sama)

Taraf nyata signifikan $\alpha=5 \%$ dengan syarat terima $\mathrm{H}_{\mathrm{o}}$ jika $F_{0}<F_{\text {tabel }}$ dan tolak $\mathrm{H}_{\mathrm{o}}$ jika $F_{0}>F_{\text {tabel }}$.

Untuk menguji hipotesis, data dianalisis menggunakan statistik uji-t dengan rumus:

$$
t=\frac{\bar{x}_{1}-\bar{x}_{2}}{\sqrt{\frac{S_{1}^{2}\left(n_{1}-1\right)+S_{2}^{2}\left(n_{1}-1\right)}{n_{1}+n_{2}-2}\left(\frac{1}{n_{1}}+\frac{1}{n_{2}}\right)}}
$$

Dengan :

$\bar{x}_{1}=$ rata-rata hasil belajar kelas eksperimen

$\bar{x}_{2}=$ rata-rata hasil belajar kelas kontrol

$S_{1}^{2}=$ varians kelas eksperimen

$S_{2}^{2}=$ varians kelas kontrol

$n_{1}=$ jumlah siswa kelas ekperimen

$n_{2}=$ jumlah siswa kelas kontrol

Sebagai kriteria pengujian hipotesis:

Terima $\mathrm{H}_{\mathrm{o}}$ jika $t_{\text {hitung }} \leq t_{\text {tabel }}$ dengan $\alpha=$ $5 \%$

Tolak $\mathrm{H}_{\mathrm{o}}$ dan terima $\mathrm{H}_{\mathrm{A}}$ jika $t_{\text {hitung }}>t_{\text {tabel }}$ dengan $\alpha=5 \%$

Hipotesis statistik yang akan diuji adalah:

$$
\begin{aligned}
& H_{O}: \mu_{A} \leq \mu_{B} \\
& H_{A}: \mu_{A}>\mu_{B}
\end{aligned}
$$

\section{Hipotesis Statistik}

$H_{O}: \mu_{A} \leq \mu_{B}$ : Rata-rata hasil belajar Fisika siswa kelas eksperimen yang diberi perlakuan dengan menggunakan e-learning berbasis edmodo lebih rendah dari pada rata-rata hasil belajar Fisika siswa kelas kontrol yang diberi perlakuan tanpa menggunakan e-learning berbasis edmodo.

$$
H_{A}: \mu_{A}>\mu_{B} \quad \text { : Rata-rata hasil belajar }
$$
Fisika siswa kelas eksperimen yang diberi perlakuan dengan menggunakan e-learning berbasis edmodo lebih tinggi dari pada rata-rata hasil belajar Fisika siswa kelas kontrol yang diberi perlakuan tanpa menggunakan $e$ learning berbasis edmodo.

\section{HASIL DAN PEMBAHASAN}

Negeri 1 Romboken pada semester genap tahun ajaran 2021/2022 pada kelas yang terpilih, yaitu siswa kelas XI IPA 1 sebagai kelas eksperimen dengan jumlah 20 siswa dan 
siswa kelas XI IPA 2 sebagai kelas kontrol dengan jumlah 20 siswa. Penelitian menerapkan pengunaan E-Learning berbasis Edmodo pada materi Suhu dan Kalor.

Data ini diambil dari hasil posttest materi Suhu dan Kalor. Rata-rata hasil belajar kelas eksperimen dan kelas kontrol berdasarkan hasil analisis deskriptif dari kedua kelas dapat dilihat pada tabel 2 .

Tabel 2. Statistik nilai posttest kelas eksperimen dan kelas kontrol

\begin{tabular}{llll}
\hline No & Statistik & \multicolumn{2}{c}{ Nilai Statistik } \\
\cline { 3 - 4 } & & $\begin{array}{l}\text { Kelas } \\
\text { Eksperimen }\end{array}$ & $\begin{array}{l}\text { Kelas } \\
\text { Kontrol }\end{array}$ \\
\hline 1. & $\begin{array}{l}\text { Skor } \\
\text { Minimum }\end{array}$ & 60 & 50 \\
\hline 2. & $\begin{array}{l}\text { Skor } \\
\text { Maksimum }\end{array}$ & 90 & 90 \\
\hline 3. & Jumlah & 1610 & 1350 \\
\hline 4. & Rata-rata & 80,5 & 67,5 \\
\hline 5. & Ragam & 78,68421 & 146,0526 \\
\hline 6. & $\begin{array}{l}\text { Standar } \\
\text { Deviasi }\end{array}$ & 8,870412 & 12,08522 \\
\hline
\end{tabular}

Pada data hasil penelitian yang tertera pada tabel di atas, diketahui pada posttest untuk kelas eksperimen skor terendah adalah 60 skor tertinggi adalah 90 sedangkan pada kelas kontrol skor terendah adalah 50 dan skor tertinggi adalah 90 .

Tabel 3. Distribusi frekuensi posttest kelas eksperimen

\begin{tabular}{cc}
\hline Interval kelas & Frekuensi \\
\hline 60 & 1 \\
\hline 70 & 4 \\
\hline 80 & 8 \\
\hline 90 & 7 \\
\hline
\end{tabular}

Tabel 4. Distribusi frekuensi posttest kelas kontrol

\begin{tabular}{cc}
\hline Interval kelas & Frekuensi \\
\hline 50 & 3 \\
\hline 60 & 6 \\
\hline 70 & 6 \\
\hline 80 & 3 \\
\hline 90 & 2 \\
\hline
\end{tabular}

Sebelum dilakukan pengujian hipotesis dengan menggunakan uji-t, terlebih dahulu dilakukan uji normalitas data menggunakan uji Lilliefors dan uji homogenitas varians. Data yang digunakan adalah data selisih Posttest dari kedua kelas yaitu kelas eksperimen dan kelas Kontrol.

\section{Uji Prasyarat}

Uji Normalitas

Uji normalitas data pada penelitian ini menggunakan uji liliefors yang diolah menggunakan software Microsoft Excel. Hasil uji normalitas dari Posttest pada kelas eksperimen menunjukan nilai $L_{\text {hitung }}=0.172$ dan $L_{\text {tabel }}=0.190$, karena $L_{\text {hitung }}<L_{\text {tabel }}$ maka terima $H_{0}$ dan data berdistribusi normal.

Sementara uji normalitas dari Posttest pada kelas kontrol menunjukan nilai $L_{\text {hitung }}=$ 0.182 dan $L_{\text {tabel }}=0.190$, karena $L_{\text {hitung }}<$ $L_{\text {tabel }}$ maka terima $H_{0}$ dan data berdistribusi normal.

Uji Homogenitas

Hasil analisis pengujian kesamaan dua varians/ragam dengan statistik uji $\mathrm{F}$ dengan $S d x 1=146.0526 \quad$ dan $\quad S d x 2=78.6842$ memberi nilai $F_{\text {hitung }}=1.8561$ sedangkan nilai $F_{\text {tabel }}=2.1682$ maka terima $H_{0}: \sigma_{1}^{2}=$ $\sigma_{2}^{2}$. Jadi, dapat dilihat bahwa varians dari kedua populasi asal sampel penelitian adalah homogen.

\section{Pengujian Hipotesis}

Dari hasil pengujian hipotesis dengan uji-t pada taraf nyata $\alpha=0,05$ diperoleh $t_{\text {hitung }}=$ 3.15186 dan nilai $t_{\text {tabel }}=t_{0,05(38)}=$ 1.68595. Jadi $t_{\text {hitung }}$ lebih besar dari $t_{\text {tabel }}$. Sesuai dengan kriteria pengujian statistik jika $t_{\text {hitung }}>t_{\text {tabel }}$ maka $H_{0}$ ditolak dan $H_{A}$ diterima. Dengan demikian dapat disimpulkan bahwa rata-rata hasil belajar siswa kelas eksperimen yang diberi perlakuan dengan menggunakan e-learning berbasis edmodo lebih tinggi dari pada rata-rata hasil belajar kelas kontrol yang diberi perlakuan tanpa menggunakan e-learning berbasis edmodo.

\section{KESIMPULAN}

Berdasarkan hasil penelitian dan analisis data pada siswa kelas XI IPA 1 dan XI IPA 2 di SMA Negeri 2 Tondano dalam pembelajaran Fisika pada materi Suhu dan Kalor maka dapat disimpulkan bahwa pembelajaran menggunakan e-learning berbasis edmodo lebih efektif karena rata-rata hasil belajar Fisika kelas eksperimen yang diberi perlakuan dengan menggunakan e-learning berbasis edmodo lebih tinggi dari pada rata-rata hasil belajar Fisika siswa kelas kontrol yang diberi 
perlakuan tanpa menggunakan e-learning berbasis edmodo.

\section{REFERENSI}

Alev Ates Cobanoglu. (2018). Student teachers' satisfaction for blended learning via Edmodo learning management system. Behaviour \& Information Technology 37 (2), 133-134, 2018

Anshori, A. (2019). Pengaruh Penggunaan Aplikasi Edmodo Terhadap Efektivitas Pembelajaran Mahasiswa Pendidikan Biologi. Jurnal Biogenerasi.

Binus University Online Learning. (2020).Pentingnya Memiliki Keterampilan Teknologi Informasi dan Komunikasi Di Era Revolusi Industri 4.0. Seminar Online

Didem Inel Ekici. (2017). The Use of Edmodo in Creating an Online Learning Community of Practice for Learning to Teach Science. Malaysian Online Journal of Educational Science 5 (2), 91-106

Imam Mudakir, Kamalia Fikri. (2018). Development of Edmodo-Based ELearning Media on the Plantae's Discussion for Learning Biological High School. Jurnal Bioedukasi, 83-89

Khaleel M Al-Said. (2015). Students' Perceptions of Edmodo and Mobile Learning and Their Real Barriers towards Them. Turkish Online Journal of Educational Technology-TOJET 14 (02), 167-180

Khasanah, O. F. (2015). Efektivitas Penggunaan Jejaring Sosial Edmodo Untuk Meningkatkan Hasil belajar Siswa Pada Mata Diklat Instalasi Sistem Operasi Gui Cli Kelas X TKJ SMK N 1 Pundong. Skripsi.

Muhajir, R. M. (2019). Efektivitas Penggunaan E-Learning Berbasis Edmodo Terhadap Minat dan Hasil Belajar (Studi Kasus di SMK Negerial Mubarkeya). Jurnal Pendidikan Teknologi Informasi.

Sugiyono. (2013). Metode Penelitian Pendidikan (pendekatan kuantitatif, kualitatif, dan $R$ \& B). Bandung: $P T$ ALFABETA.

Suharti. (2021). Efektivitas Penerapan Media Pembelajaran Interaktif Berbasis Edmodo Dalam Menyongsong Era Revolusi Industri 4.0 Terhadap Hasil Belajar Matematika Siswa. Jurnal Cendekia, Jurnal Pendidikan Matematika.
Sudjana. (2009). Metoda Statistika. Bandung: tarsito.

Wawo, D. N. (2017). Efektvitas Penggunaan Model Pembelajaran Berdasarkan Masalah (Problem Based Instruction) Terhadap Proses Dan Hasil Belajar Siswa. Skripsi

W Wibowo, N Astriawati. (2020). The effectiveness of using Edmodo based elearning in the applied mechanics course. Journal of physics 